\title{
TWO EB III RED POLISHED JUGS \\ FROM PALACE B IN KHIRBET AL-BATRAWY \\ AND JUGS WITH RESERVED ALTERNATE-HATCHING DECORATION (RAHD) FROM PALESTINE AND TRANSJORDAN*
}

\author{
Chiara Fiaccavento - Sapienza University of Rome
}

The Early Bronze Age III (around 2700-2350 BC) represents the zenith of the Southern Levantine cities of the $3^{\text {rd }}$ millennium $B C$, both in terms of growth and social complexity. Between the numerous valuable items (high-quality stone objects, metal weapons, Egyptian or Egyptian-style luxury pieces, jewels) gathered by local élites inside temples and palaces, or preserved as heirlooms in grave goods, a specific typology of ceramic vessels seems to be linked to these prestigious contexts: redburnished/polished jugs, with a reserved decorated band on the girth in form of diagonal burnished hatching. Two jugs recently recovered from the EB IIIB Palace B of Khirbet al-Batrawy (NorthCentral Jordan) have allowed an evaluation of this decorative motif with its related retrieval contexts.

Keywords: red-polished jugs; hatched reserved burnishing; Khirbet al-Batrawy; Early Bronze III; urbanism and status display

\section{THE AFFIRMATION OF CITY-STATES SYSTEM AND THE COLLECTION OF LUXURY OBJECTS}

In the passage between Early Bronze I and Early Bronze II (3200-3100/3000-2700), ${ }^{1}$ from a not-organically structured society studded with numerous small villages to the appearance of a few major cities, ${ }^{2}$ several elements in architecture ${ }^{3}$ and material culture ${ }^{4}$ highlighted this social change.

* Grateful thanks are addressed to Prof. Lorenzo Nigro, for encouraging and training me in the research on the Early Bronze Age and for charging me with this study, discussing thoroughly with me many issues of it, and to Maura Sala, for having patiently shared her knowledge of EB pottery with me throughout these years.

1 In the present contribution, traditional Early Bronze II-III chronology (3050-2300 BC: Mazar 1990, 108-110) has been kept basically unchanged. Recent debate on EB chronology, and new calibrated radiocarbon dating, brings back the beginning and the end of the EB II-III, fixing the end of the EB II between 3000-2900 BC, and the end of the EB III around 2500 BC (Regev et al. 2012). For an overview of Egyptian artifacts retrieved in Transjordanian contexts (and at Khirbet al-Batrawy itself) during the Early Bronze II-III, with the related chronological implications, see Nigro 2014a, 46-47; Sala 2014.

2 Speculative approaches to Early Bronze Age walled sites characterized them in different levels of social complexity as cities within secondary states (Esse 1989), city-states (de Miroschedji 2009) or corporate villages (Chesson - Philip 2003; Philip 2008). It is difficult to come to a shared agreement, since the $3^{\text {rd }}$ millennium panorama in Southern Levant appears highly diversified, and also if general tendencies can be pointed out, no theoretical model succeeds in meeting the totality of the cases. Nevertheless some EB III centers have those characteristics belonging to what can be considered a local way to urbanism (Nigro 2009).

3 The erection of the first massive defensive systems (Mazar 1990, 119-123) and the appearance of temples (Sala 2008, 121-186), took place between EB I and EB II (see e.g. the monumental temple of Megiddo in level J-4/stratum XVIII, corresponding to EB IB: Adams - Finkelstein - Ussishkin 2014).

4 The regional material fragmentation detectable in the Early Bronze I pottery underwent a general standardization in terms of paste and shapes in the following EB II, with the emergence of a southern horizon (Amiran 1969, 58-59) and a northern one (Greenberg - Porat 1996); during the EB III the homogenization became much more evident with the sole exception of the KKW (see below fn. 6). 
Nevertheless, the apex of the urban culture was reached nothing but in the EB III (2700$2350 \mathrm{BC}$ ), when most of the cities stretched to their maximum extension, ${ }^{5}$ with the achievement of an almost full degree of homogenization in material culture, ${ }^{6}$ and the emergence of the first buildings erected for housing local élites, ${ }^{7}$ i.e. central institutions ruling over major cities. One of the principal functions of the palaces was certainly gathering in secure places (the fortified cities) foodstuff and other staple goods: ${ }^{8}$ with the latters, or through/in function of them, the central institutions gathered also immaterial resources as power and control over the incomes tied to the land (water and agro-pastoral products). Other kinds of immaterial resources became as important as the material ones, if not more: control over craft production (and over the ability and the possibility to reproduce that $\mathrm{craft})^{9}$ and trade connections, ${ }^{10}$ whose material outcomes were stored in the palace itself, as physical representations of an intangible status. ${ }^{11}$ Between these prestige objects, a new class of jugs with a particular reserved decoration on the girth seems to be related to some EB III public contexts, or funerary ones. Significantly not one of these pieces derived from an EB II context, not even in those cases that demonstrate a noteworthy accumulation

5 In the passage between EB II and EB III, many fortification systems of Palestinian cities are strengthened or doubled with the addition of advanced defensive works or towers, such as, for instance, at et-Tell/“Ai (Callaway 1980, 147-158), Khirbet Yarmouk (de Miroschedji 1990, 57-60), Tell es-Sultan/Jericho (Nigro 2014c, 73, n. 14 with previous references), Khirbet al-Batrawy (Nigro 2012, 38-52; Nigro ed. 2008, 89-95), Khirbet Kerak (Greenberg et al. 2006, 249-267), Khirbet ez-Zeraqon (Lower City: Douglas 2007, 30, figs. 4, 14-18, 26, plans 6-9). This general strengthening of fortifications, likely due to an higher level of conflict between the Levantine city-states, can be seen also as a positive response to the catastrophic telluric struck that hit the region at the end of EB II (for a recent summary on this topic see Gallo 2014, 146-153).

6 Despite the phenomenon of the so-called Khirbet Kerak Ware (KKW), whose foreign origin and northern derivation justify the outstanding difference in manufacturing technique, typology and decoration in respect to the rest of the local repertory (Greenberg - Goren eds. 2009), EB III pottery underwent a general standardization, marginalizing or losing completely the specialized productions of EB II, such as North Canaanite Metallic Ware (Greenberg - Porat 1996) or Light Faced Painted Ware/Abydos Ware (Amiran 1974; Kantor 1992).

7 The evidence of Southern Levantine palaces (as attested at Palace B of Khirbet Yarmouk - de Miroschedji 2003; Palace 3177 of Tell el-Mutesellim/Megiddo - Loud 1948, 70-78; Nigro 1994, 1-27; the 'palace' in the Upper City of Khirbet ez-Zeraqon - Genz 2002, 96, fig. 6.2; Palace B at Khirbet al-Batrawy - § 2.), i.e. residences of an institutionalized ruling class, is basically restricted to EB III (Nigro 1994, 5-7, 16-27; Genz 2010) thus in a secondary moment compared to temples (fn. 3), with the possible exception of the commercial building at Tell es-Sa'idiyeh (Field 1, Stratum L2) of the EB II (Tubb - Dorrell - Cobbing 1997, 55-65). It is always in the passage between EB II-EB III as well during EB III that larger buildings destined to communal functions were built, e.g. the so-called Granary of Khirbet Kerak (Greenberg et al. 2012, 97-102).

8 The principal function of accumulation of primary goods performed by EB palaces is well attested by the high number of storage containers filling them (Genz 2010).

9 About the use and the significance of potters' wheels in EB public contexts see Fiaccavento 2013, 86-88; Roux - de Miroschedji 2009

10 See Nigro 2014a, on the role and the importance of copper/copper items trade in EB Southern Levant, with a special focus on Khirbet al-Batrawy.

11 Chesson - Goodale 2014, 122-124. 
of wealth, as verifiable in the public building of Tell es-Sa'idiyeh ${ }^{12}$ or in the public complexes of Arad. ${ }^{13}$

\section{THE KHIRBET AL-BATRAWY SPECIMENS FROM PALACE B}

The $3^{\text {rd }}$ millennium city of Batrawy arose over a high khirbet dominating the valley of Upper Wadi az-Zarqa. ${ }^{14}$ Its lifespan covers EB II-III periods, giving back a continuous stratigraphic sequence with three major phases (EB II, EB IIIA, EB IIIB), marked by destructions and rebuilding, showing the flourishing but alternate fate of one of the principal centres of the EB urban phase on the eastern side of the Jordan river. ${ }^{15}$

Despite the massive fortifications on triple lines that surrounded the city, ${ }^{16}$ and its uncomfortable position to attack, Batrawy was totally destroyed at the end of EB III, during EB IIIB, and reoccupied shortly and in a village-dimension only after a certain lapse of time, in EB IVB. ${ }^{17}$ This stratigraphic superposition allowed to perfectly preserve, immediately inside the northern defence walls, a major EB II-III public building - Palace B - consisting so far of two symmetrical pavilions, each being made up of a main rectangular hall with auxiliary rooms to the south. ${ }^{18}$

Hundreds of ceramic containers along with many others high-status and rare items ${ }^{19}$ were carefully gathered inside the palace, especially in the Western Pavilion, composed of Pillared Hall L.1040, Hall L.1110, Storeroom L.1120. ${ }^{20}$

Between these precious goods a jug with a distinctive and carefully refined decoration was retrieved in the destruction layer of Hall L.1110, jug KB.11.B.1128/49 ${ }^{21}$ (tab.1:1; fig. $1: 1)$. It shows an ovoid body, with short cylindrical neck, out-flaring rim and narrow flatted base. It is high $36 \mathrm{~cm}$ and large, at the maximum point of the girth, $30 \mathrm{~cm}$. The outer decoration is both colouristic and plastic. Plastic, since it is characterized by the presence of two small rounded knobs applied at the bottom of the neck, and one flattened vertical ridge at the girth of the body. Colouristic because the real specificity of the jug remains the

12 On the lower tell of Tell es-Sa'idiyeh a large EB II palace complex has been discovered with areas destined for olive oil production and storage, wine-making and textile preparation (Tubb 1993, 1300).

13 Amiran et al. 1978.

14 The exploration of Khirbet al-Batrawy was carried on for nine seasons (2005-2013): the results of the excavations are illustrated mainly in five preliminary reports (Nigro ed. 2006; 2008; 2011; Nigro 2010a), as in several specific studies (Nigro 2011; 2014a; 2014b, 2014c, with previous references).

15 For an assessment of the Batrawy stratigraphic phases on ceramic bases see Sala 2013.

16 Nigro ed. 2008, 89-101; Nigro 2009, 667-669; 2010b, 438-440; 2013, 197.

17 Nigro - Sala 2011, 88-89; 2012, 46-47; Sala 2012.

18 For a complete overview of the architecture of the Palace see Nigro 2014a, with previous references.

19 Between the rank objects gathered in Palace B remarkable is the presence of four copper axes and a dagger (Nigro 2010a, 73-74; 2010c, 568-570), a complete gemstone necklace (Nigro 2012), a ceremonial pedestalled krater (Nigro 2014a; 2014b), a lotus-shaped vase and an Egyptian palette (Nigro 2014a; Sala 2014); it is noteworthy that inside the palace there was also an accumulation of technical skills and innovative means, as testified by the presence of three potter's wheels (Fiaccavento 2013).

20 These rooms are those completely excavated so far, two other - L.1250, L.1230 - are still under investigation (Nigro 2014a).

21 KB.11.B.1128/49, from destruction layer F.1128, in Hall L.1110 (square BmII8), Batrawy III (activity 3b); see particularly Nigro 2012, 228; Nigro - Sala 2012, 51, fig. 14. 
decoration: over an highly red polished body, a reserved band shows a pattern in form of alternating-hatched burnishing (thus with an alternation of matte and burnished diagonal lines). The band is high about $3 \mathrm{~cm}$, each alternated trapezoid having the larger part of around $5-6 \mathrm{~cm}$ and the narrower one of $2-2.5 \mathrm{~cm}$; the decorative motif probably began to be drawn starting from the ridge and turning the object, without regard to the junction point of the band around the ridge, thus resulting slightly unaligned. The type of applied décor is not unique, other luxury specimens in the Batrawy Palace itself $^{22}$ (fig. 1:2) as well in other EB sites show the same ornamental motives $(\S 3$.$) , maybe formerly intended for a functional$ use $^{23}$ and then changed in shape but remained in heritage in a stylistic continuity, with the partial loss of their original practical purpose. In this specific case, on the basis of the combination between plastic and colouristic decorations, another reading can be tentatively put forward, and will be illustrated below (\$ 4.).

It is remarkable that another smaller red burnished jug with a particular decoration, unfortunately in a fragmentary status, derives from the same stratigraphic context in L.1110, jug KB.11.B.1128/65 (tab. 1:2; fig. 1:2). The preserved part of its body, over the girth, shows a single vertical ridge $5 \mathrm{~cm}$ high and 0.7 wide, and a continuous reserved band around $2 \mathrm{~cm}$ high, in this case embellished with a cross-hatching decoration, dividing the body in two parts which in turn are vertically burnished. ${ }^{24}$

\section{OTHER EXEMPLARS SHOWING RAHD: SHAPES AND CONTEXTS}

Red polished jugs from Khirbet al-Batrawy are not the sole specimens of this class recovered from an EB III context: at least 5 other examples can be ascribed to the same decorative idea and particular technique (tab. 1). Two large jugs from Tell elMutesellim/Megiddo are pretty well-known, since recently restored and republished with their complete shapes $(\S 3.1$.$) , the others are from funerary contexts, one from Tell es-$ Sultan/Jericho (§ 3.2.) and one from Bab edh-Dhra' (§ 3.3.). Finally, another little jug deriving from the Hebron area $(\S 3.4$.), unfortunately without a certain context, bears the same precious technique.

22 Another complete jug (KB.11.B.1124/36) from the palace shows the combination of burnished decoration, knobs and ridges even if lacking the reserved band that is the own characteristic of the production.

23 Real handles located on the girth of jars/jugs (or on other forms, as vats) are attested since EB I: during EB IIIII most of the girth-handles met a process of flattening and narrowing, until changing into simple ridges (often described also as "vestigial handles"), without a clear practical use. The knobs, instead, were probably used to secure with ropes the leather lids of the containers, thus absolving a practical aim, rather than a merely aesthetic one.

24 This is not the only specimen with this kind of reserved decoration: a black slipped jug from Tomb F4 in the Jericho, with globular body, stump base and two small vertical lugs at girth, interestingly shows a trellis pattern (or cross-hatched burnishing) on the girth (Kenyon 1960, 134, fig. 45:5), in a kind of external treatment emerged at Megiddo (Greenberg 2006, fig. 10.9: 6-7; Adams 2013a, 325-327) and Hazor (Greenberg 1997, 21, fig. II.3:12) as well (in these last cases on the entirety of the body), and linked to the northern horizon of Byblos (Saghieh 1983, pls. 35-36, 50-51), where this type of decoration began to be attested in EB III (local Level KIII). 


\begin{tabular}{|c|c|c|c|c|c|c|}
\hline \multirow[t]{2}{*}{$\begin{array}{l}\text { CAT. } \\
\text { (PL:NO) }\end{array}$} & \multirow[t]{2}{*}{ SITE } & \multirow[t]{2}{*}{$\begin{array}{l}\text { TYPE OF } \\
\text { CONTEXT }\end{array}$} & \multirow{2}{*}{$\begin{array}{l}\text { RESERVED } \\
\text { ALTERNATE- } \\
\text { HATCHING } \\
\text { DECORATION } \\
\text { (RAHD) }\end{array}$} & \multicolumn{2}{|c|}{$\begin{array}{l}\text { PLASTIC } \\
\text { DECORATIONS }\end{array}$} & \multirow{2}{*}{$\begin{array}{l}\text { BIBLIOGRAPHY } \\
\text { (MAIN } \\
\text { PUBLICATION, } \\
\text { FOR OTHERS SEE } \\
\text { INFRA) }\end{array}$} \\
\hline & & & & $\begin{array}{l}\text { KNOBS } \\
{[\mathrm{K}]}\end{array}$ & $\begin{array}{l}\text { VERTICAL } \\
\text { RIDGES } \\
{[\text { VR] }}\end{array}$ & \\
\hline $1(1: 1)$ & $\begin{array}{l}\text { Khirbet al- } \\
\text { Batrawy }\end{array}$ & Palatial & 1 & $\mathrm{x}$ & $\mathrm{x}$ & $\begin{array}{l}\text { Nigro - Sala } \\
2012 \text {, fig. } 14,51\end{array}$ \\
\hline $2(1: 2)$ & $\begin{array}{l}\text { Khirbet al- } \\
\text { Batrawy }\end{array}$ & Palatial & $1^{25}$ & - & $\mathrm{x}$ & unpublished \\
\hline $3(3: 1)$ & $\begin{array}{l}\text { Tell es-Sultan / } \\
\text { Jericho }\end{array}$ & $\begin{array}{l}\text { Funerary } \\
\text { (Tomb A) }\end{array}$ & 1 & $\mathrm{x}$ & $\mathrm{x}$ & $\begin{array}{l}\text { Garstang 1932, } \\
\text { pl. VIII:6 }\end{array}$ \\
\hline $4(3: 3)$ & Bab edh-Dhra' & $\begin{array}{l}\text { Funerary } \\
\text { (Tomb A8) }\end{array}$ & 1 & $\mathrm{x}$ & $\mathrm{x}$ & $\begin{array}{l}\text { Rast - Schaub } \\
\text { 1989, fig. 202:2 }\end{array}$ \\
\hline $\begin{array}{l}5,6(3: 5- \\
6)\end{array}$ & $\begin{array}{l}\text { Tell el- } \\
\text { Mutesellim / } \\
\text { Megiddo }\end{array}$ & $\begin{array}{l}\text { Cultic / } \\
\text { Public }\end{array}$ & 2 & - & $\mathrm{x}$ & $\begin{array}{l}\text { Adams 2013a, } \\
\text { figs. 8.14:2-3, } \\
8.15,324-325\end{array}$ \\
\hline $7(3: 2)$ & Beit Ula & Funerary & 1 & $\mathrm{x}$ & $\mathrm{x}$ & unpublished $^{26}$ \\
\hline
\end{tabular}

Tab. 1 - Table of jugs with Reserved Alternate-Hatching Decoration (RAHD).

\subsection{Tell el-Mutesellim/Megiddo}

The renewed excavations ${ }^{27}$ in the Jezreel Valley at Tell el-Mutesellim/Megiddo, in Area $\mathrm{J}$, have further refined the EB stratigraphic sequence of the acropolis, a space consisting of several terraces, where the religious and political compound of the ancient city with its monumental structures was established during EB IB. ${ }^{28}$ During the EB III (levels J-5 and J$6)^{29}$ on the eastern terrace was constructed a large palatial building, ${ }^{30}$ whereas on the upper western terrace a larger composite urban space included a round altar and flagstone-paved streets flanked by public buildings. ${ }^{31}$ Inside one of them there was a sort of minor cult installation $^{32}$ surrounded by an elaborately paved 'red-sherd' floor, Floor $98 / \mathrm{J} / 76 .{ }^{33}$ From

25 The decoration in this case is reserved cross-hatched and not alternate, see the description supra and fig. 1:2.

26 The author wishes to thank Osnat Misch-Brandl, curator of the "Land of Canaan" section of the Israel Museum of Jerusalem, for the details given about this object. See also Pelta 2013.

27 Gottlieb Schumacher conducted the first excavations at the site from 1903-1905, on behalf of the German Society for Oriental Research. Excavations at Megiddo were renewed in 1925 by the Oriental Institute (OI) of the University of Chicago. In the late 1960s and early 1970s short seasons were carried out by the Hebrew University of Jerusalem, and resumed (and still ongoing) under the auspices of the Tel Aviv University in conjunction with the George Washington University. The area of the acropolis was explored only by the OI (Area BB - Strata XX-XVI; Loud 1948) and by the latest excavations.

28 Level J-4/Stratum XVIII. Adams 2013b, 50-79; Adams - Finkelstein - Ussishkin 2014.

29 Strata XVII-XVI of Oriental Institute Excavations (Loud 1948, figs. 392-393). Following the stratigraphic interpretation of recent excavations, EB II at Megiddo is represented by a phase of ephemeral and squatter occupation after the destruction of the Great Temple (J-4a: Finkelstein - Ussishkin 2000, 585-586; Adams 2013b, 74-76).

30 OI building 3177 (Loud 1948, 70-78, figs. 392-393; Nigro 1994, 1-27).

31 Adams 2013b, 82-94.

32 The feature $(04 / \mathrm{J} / 62)$ was composed by four flat-topped stones neatly arranged around a smaller flat-topped stone, creating a round flat table, used to support some sort of icon. This could not be interpreted as a column base since built up against one of the walls of the room (Phase J-6a: Adams 2013b, 91-93). 
this floor, which contained more than 18 different vessels in shards, derived two large jugs showing the RAHD. ${ }^{34}$ One was preserved with its complete shape, the other was partially broken, missing the neck, but both bore the decoration and a similar form (fig. 2:4-5). ${ }^{35}$ Both the jugs had flat base, rounded walls, short cylindrical neck and out-flaring rim, with single handle from rim to shoulder. The surface is vertical burnished from the base to the decorated strip (wide in one case $2 \mathrm{~cm}$ and in the other $3 \mathrm{~cm}$ ), and diagonal, following the inclination on the upper part of the body, until the neck. Both of them showed the vertical ridges, but not the knobs.

\subsubsection{An experimental study on the RAHD of the Megiddo jugs}

The distinction of the decoration over the Megiddo jugs led R. Pelta to try experiencing the technique of manufacture that produced this specific motif. ${ }^{36}$ Through the reproduction of different decoration techniques, the scholar achieved to replicate the effect visible on jug $98 / \mathrm{J} / 76 \mathrm{VS} 12$, thus understanding the chaîne opératoire undertaken by the potter. The decoration was attained through three passages: 1) complete slipping of the vessel; 2) horizontal and vertical burnishing of the upper and lower areas, leaving an un-burnished matte strip between them; 3) burnishing of the band creating diagonal burnished lines (each consisting of multiple burnished lines) and leaving light-coloured matte lines in-between. ${ }^{37}$

Since it is very likely that it existed a single production centre for this type of unique decoration ( $§ 5$.), the conclusions reached by this study on the Megiddo specimens can be relevant also for all the other specimens hereby reported.

\subsection{Tell es-Sultan/Jericho}

Tell es-Sultan/Jericho necropolis was one of the largest of the Southern Levant, ${ }^{38}$ the existence of which was primarily recognized, even if not with the awareness of its huge extension, by J. Garstang in 1931. The first discovered tomb was Tomb A, from which the juglet with RAHD derives; it was a collective burial (hosting more than five hundreds individuals) excavated in the limestone plateau west of Tell es-Sultan, roughly squareshaped (around $5.0 \times 5.0 \mathrm{~m}$ ) with a reserved pillar in the middle. ${ }^{39}$ Between the rich pottery

33 The name derives from the high concentration of red-burnished/polished vessels in fragments composing it (Finkelstein - Ussishkin - Peersman 2006, fig. 3.27; Adams 2013b, fig. 2.53).

34 Phase J-6a 98/J/76VS11-12 (Adams 2013a, 324-325, figs. 8.14:2-3; 8.15). They were published by R. Greenberg (2006, 165, fig. 10.10:1-2) who primarily recognized the specific decoration, naming it "reserved burnish".

35 A third jug in the same context, very similar for dimensions and exterior burnishing, unfortunately was missing of the central part of the body where the decoration is attested (Adams 2013a, fig. 8.14:1).

36 Pelta 2013

37 Pelta 2013, 337-341, figs. 9.4-9.6. Interestingly, this procedure is also the more direct one between those experimented, even if required a great expertise in the techniques of slipping, burnishing and firing.

38 The total number of the tombs is more of 500, spanning primarily from Early Bronze to Middle Bronze Age (i.e. the apex periods of the Jerichoan culture - even if the great majority of MB burials were in re-used EB IV tombs), with scarce evidences of later epochs (Late Bronze, Iron Age and Roman Period) (Garstang 1932; 1933; 1934; Garstang - Droop - Crowfoot 1935; Garstang - Ben-Dor - FitzGerald 1936; Kenyon 1960; 1965).

39 Garstang 1932, 18-22, fig. 7, pls. XVII, XXI-XXIII, XXVI. 
assemblage, dated back mostly to EB II-III, ${ }^{40}$ one jug with a typical shape of the EB III, that is the presence of a high stump base, ${ }^{41}$ sustaining a globular body, with loop handle and wide mouth, showed a decoration in form of a single band horizontally subdivided in two mirrored strips, with the same alternation of burnished hatching (fig. 2:1); this is the only exemplar that exhibited the decoration on a doubled line. Also in this case there are two knobs at the basis of the neck and the vertical ridge on the girth. Other specimens in the same tomb had the applied elements (both features or just one, generally the ridge),${ }^{42}$ but none had that specific decoration. ${ }^{43}$ In other tombs too, ${ }^{44}$ as well as on the tell, ${ }^{45}$ there were several jugs or juglets with applied plastic knobs or ridges.

40 Garstang 1932, pls. II-VIII, XXVII-XXVIII. This huge familiar tomb seems to be inaugurated already during EB I (as attested by some ceramic forms - Garstang 1932, pls.VIII:1-4, XXVIII:3-5) but was mostly in use during the urban period, until early EB IIIB (Sultan IIIc2). For a punctual description (and distinction) of EB II pottery in Garstang's Tomb A see Nigro 2010d, 211-213, pls. LIX-LXI.

41 Garstang 1932, pl. VIII:6; thick stump-bases or pointed/spike-like bases are typical of jarlets and jugs/juglets of the Early Bronze III (e.g. Megiddo: Loud 1948, pl. 5:1; Greenberg 2006, figs. 10.4:13, 10.7:8; or Khirbet Yarmouk: de Miroschedji 2000, fig. 18.6:3)

42 Garstang 1932, pls. II:10, VII:1,3,6-7.

43 See the description of a jug from Tomb F4 (fn. 24), with a cross-hatched decoration, that can share the same decorative concept with that here outlined.

44 In Tomb D12, described by K.M. Kenyon as «the tomb that contained the best and largest collection of EB III pottery found at Jericho» (Kenyon 1960, 94-96, fig. 32), the numerous pieces showing knobs or ridges, or both, are shown below: upper part of a burnished jug with double knobs at the base of the neck (Kenyon 1960, 99, fig. 34:3); 4 juglets with two vertical lugs at girth (Kenyon 1960, 102, figs. 34:19,24,26,27); lower part of a burnished globular juglet with double knock and vertical ridge (Kenyon 1960, 102, fig. 34:25); burnished globular juglet with pointed base and double knobs (Kenyon 1960, 108, fig. 35:35); burnished jug with globular body and flat base, two knobs (Kenyon 1960, 111, fig. 36:25); pink slip jug with wide mouth, pointed base two opposed vertical lugs on girth and single knob on shoulder, opposite handle (Kenyon 1960, 112, fig. 37:6); black slipped juglet, globular body, everted rim, spike base, two vertical lugs on body, two knobs on shoulder opposite handle (Kenyon 1960, 117, fig. 37:48); black slipped juglet, everted rim and spike base, three vertical lugs on girth (Kenyon 1960,117, fig. 37:47); red burnished jug, vertical lugs on globular body, one preserved knob (Kenyon 1960, 121, fig. 39:2); red burnished jug with slender body, two vertical lugs at girth; brown burnished jug with two vertical lugs at girth (Kenyon 1960, 121, fig. 39:3); red slipped juglet, globular body and spike base, with two vertical lugs on shoulder, pair of knobs on shoulder opposite handle (Kenyon 1960, 123, fig. 39:11). Other 3 specimens derived from Tomb F2: red burnished jug with globular body and flat base, pair of nipples on shoulder, a raised bar on each side (Kenyon 1960, 162, fig. 59:5); red burnished jug with globular body and flat base, a nipple on shoulder opposite handle, a raised bar on each side (Kenyon 1960, 162, fig. 59:6); globular juglet with two nipples on shoulder (Kenyon 1960, 168, fig. 61:18)

45 Significantly a red-burnished jug with applied knobs has been retrieved in EB IIIB Palace G (TS.10.G.1172/49; Nigro et al. 2011, fig. 19); another derives from Site L: a buff burnished jug, with rounded body and narrow flat base, with two plastic knobs on shoulder (Kenyon - Holland 1983, 476, fig. 213:4) 


\subsection{Bab edh-Dhra'}

The huge Early Bronze (I-IV) necropolis of Bab edh-Dhra' in the Ghor, which stands out for the peculiarity of its funerary customs during the EB urban period, ${ }^{46}$ gave back one jug with RAHD. The specimen was found in Charnel House A8, a broadroom building of parallelepiped shape, with the entrance slightly off centre on the southeast side, and the threshold slab still in situ. ${ }^{47}$ Between the complete pottery vessels located into the tomb, whose shapes belonged both to EB II that EB III, a jug with tall and flat stump base (thicker than wall), rounded body, handle from shoulder below a rim sharply flared, bore two knobs and a raised ridge on the central part of the body, with a reserved band of "angled burnish strokes", high around $3.5 \mathrm{~cm}$ (fig. 2:3). ${ }^{48}$ In the same funerary chamber another jug showed the combination knobs/ridge ${ }^{49}$ and other two just the ridges. ${ }^{50}$ As already observed at Tell es-Sultan, several other exemplars presented the plastic applied decorations,${ }^{51}$ but none the reserved one. $^{52}$

\subsection{Beit Ula}

One last jug belongs to this class. Its acquisition by the Israel Museum of Jerusalem prevented its loss in favour of a private collection, but without bridging the gap of information about its retrieval context. The only available datum is the area of origin, that is the Palestinian village of Beit Ula in the Hebron Hills, ten kilometres northwest of Hebron. Anyway, seen the integrity of the object it is easy to suppose that it was part of the grave goods of an EB III tomb. It presents a flattened circular base, globular body, short neck and everted rim, with the handle from the rim to the shoulder (fig. 2:2); it is $20 \mathrm{~cm}$ high, with a maximum diameter of $17 \mathrm{~cm}$, double knobs on the shoulder and vertical ridge on the

46 Funerary practices at Bab edh-Dhra' show an evolution in EB IB correlated to the establishment of a stable village, switching from shaft or cist tombs to built-up structures, the Charnel Houses (first circular and then rectangular), which remained in use until the end of the urban phase of the walled city (established in EB II and lasted during EB III), and getting back again to shaft-tombs (even if built underground) in the EB IV village phase (Rast - Schaub 1989).

47 In respect to other Charnel Houses Tomb A8 was not particularly well built nor well-preserved: it lacked of certain typical features of these funerary structures as a small forecourt in front of the entry, or two large doorjambs (smoothed or dressed) flanking the entry on both sides (Rast - Schaub 1989, 319); other elements as the floor (generally slab-paved) were maybe unfinished or partly robbed, the bones were fewer than in other charnel houses and the entire structure suffered of an intense fire. The dating of the destruction layer through $\mathrm{C} 14$ on a piece of burnt cloth gave a date recalibrated to 3035-2535 BC (Rast - Schaub 1989, 325 326).

48 Rast - Schaub 1989, 330, fig. 202:2.

49 Rast - Schaub 1989, 330, fig. 202:1.

50 Rast - Schaub 1989, 330, fig. 202:7,36.

51 Other jugs/juglets derived from the necropolis are: 4 from Charnel House A41 (one with a "vestigial handle": Rast - Schaub 1989, fig. 218:3; one with dots on shoulder, ridge at neck, vestigial straps: Rast - Schaub 1989 , fig. 220:11; two with vestigial straps: Rast - Schaub 1989, fig. 231:8,32); 1 from Charnel House A44 (with dots on the shoulder: Rast - Schaub 1989, fig. 230:6).

52 Another juglet from Bab edh-Dhra' (Charnel House A 44: Rast - Schaub 1989, fig. 231:27) can be tentatively ascribed to a similar decorative concept : black/grey burnished ware, it reproduces the alternate-hatching motif on the shoulder, and on the neck in a diagonal band, but in form of incised band instead of the burnishing technique. 
maximum width of the body. The decoration is particularly refined: over the highly red polished body sticks out a band $2.5 \mathrm{~cm}$ high, where the alternation of the hatching bands is more spaced, resulting in less changes of orientation and in a more graphical style.

\section{A CERAMIC REPRODUCTION OF A MORE PRECIOUS PROTOTYPE?}

A careful consideration of all the parts composing the body of the jugs, especially regarding the central strip and the applied decorations, could be tentatively lead to read them as decorative reproductions of a copper prototype.

All the RAHD jugs, in facts, seemed to be composed by four parts and six elements in all. Starting from the top (fig. 3):

1 rim and neck, fixed to the body through (2); $1^{\text {st }}$ part

2 two rivets, that is the pair of knobs reproduced on the upper part of the body, immediately under the neck;

$$
2^{\text {nd }} \text { part }
$$

3 the upper half of the body;

4 a horizontal mid-band made by two twisted foils of copper, tied up by vertical clamps;

5 vertical tenons (one or more to fix the union strip of the two parts of the body);

6 the lower half of the body.

$4^{\text {th }}$ part

Significantly in the literature the vertical ridges have been also defined as "straps", ${ }^{53}$ so recalling in the description an hypothetical primary function that involved a 'fixing aim' of the ridges. Plus, this would not be the first example of ceramic reproduction of copper luxury vessels, integral part of display repertory of palatial élites, ${ }^{54}$ even if often not preserved as well in the archaeological record as like as the pottery specimens.

The horizontal shape of the rim (like Iron Age horizontally expanded rims of Phoenician oil juglets), the junction between the two halves of the original vessels, as well as the twisted band fixing them with the straps, are all easily readable details supporting such an interpretation.

The presence of two jugs with this kind of the decoration in the same room amounts the possibility that they were a couple intended as a wine set, which is linkable to an élite milieu appearing in Southern Levantine archaeological record during the apogee of the urban period (EB III).

53 In the short inventory description of the jug from Bab edh-Dhra'(fig. 2:3; § 3.3.), the object was described along these lines: "band of angled burnish strokes mid-body, raised dots on shoulder, straps mid-body" (Rast Schaub 1989, 330, fig. 202:2).

54 The presence of pottery vases reproducing metallic prototypes is well attested from the Middle Bronze Age onwards. Even more interesting in this sense seems to be the influence exerted by the northern center of Byblos, where a bronze bowl in the Montet's foundation jar, provided a good metallic prototype for the MB pottery vessels (Tufnell - Ward 1966, fig. 9:207). Already in the last phase of EB III Byblos would have strong connection and influence on the Southern Levant (fn. 24). 


\section{Catalogue}

No. 1. - Red polished jug with Reserved Alternate-Hatching Decoration (fig. 1:1)

Original number: KB.11.B.1128/49. Provenance: Khirbet al-Batrawy. Excavation: Rome «La Sapienza» Expedition to Palestine and Jordan (ROSEPAJ); Area: B South. Locus: F.1128. Square: BmII8. Activity: 3 (= EB III). Class: Red Polished Ware. State of preservation: whole shape. Technique of manufacture: coil-built, wheelturned. Fabric colour: Outer 2.5YR 6/6 (light red) + inner 2.5Y 6/1 (gray). Surface Treatment: Polished slip 10R 4/8 (red). Decoration: outer applied ( 2 knobs and 1 ridge) + outer reserved burnished. Rim diameter: $8.5 \mathrm{~cm}$; base diameter: $6.7 \mathrm{~cm}$; body diameter $(\max ):. 30 \mathrm{~cm}$; rim width: $0.55 \mathrm{~cm}$; wall width: $0.65 \mathrm{~cm}$. Dating: EB IIIB. Bibliography: Nigro - Sala 2012, 51, fig. 14

No. 2. - Red polished jug with cross-hatching decoration (fig. 1:2)

Original number: KB.11.B.1128/65. Provenance: Khirbet al-Batrawy. Excavation: Rome "La Sapienza" Expedition to Palestine and Jordan (ROSEPAJ); Area: B South. Locus: F.1128. Square: BmII8. Activity: 3 (= EB III). Class: Red Polished Ware. State of preservation: wall. Technique of manufacture: coil-built, wheel-turned. Fabric colour: Outer 2.5YR 6/6 (light red). Surface Treatment: Polished slip 10R 4/8 (red). Decoration: outer applied (1 vertical ridge) + outer reserved burnished. Wall width: $0.65 \mathrm{~cm}$. Dating: EB IIIB. Bibliography: unpublished.

No. 3 - Red polished jug with Reserved Alternate-Hatching Decoration (fig. 2:1)

Provenance: Tomb A, Tell es-Sultan/Jericho. Excavation: Marston-Melchett Expedition (Garstang); Class: Red Polished Ware. State of preservation: complete. Technique of manufacture: coil-built, wheel-turned. Surface Treatment: Polished slip. Decoration: outer applied ( 2 knobs +1 vertical ridge $)+$ outer reserved burnished. Dating: EB IIIB. Bibliography: Garstang 1932, pl. VIII:6.

No. 4 - Red polished jug Reserved Alternate-Hatching Decoration (fig. 2:2)

Provenance: unknown (Israel Museum, Jerusalem, inv. $\mathrm{n}^{\circ}$ 71.9.295), Beit Ula area (Hebron); Class: Red Polished Ware. State of preservation: complete. Technique of manufacture: coil-built, wheel-turned. Surface Treatment: Polished slip . Decoration: outer applied $(2$ knobs +1 vertical ridge $)+$ outer reserved burnished. Dating: EB IIIB. Bibliography: unpublished.

No. 5 - Red polished jug with Reserved Alternate-Hatching Decoration (fig. 2:3)

Provenance: Charnel House A8, Bab edh-Dhra'. Excavation: Dead Sea Plain Expedition; Class: Red Polished Ware. State of preservation: complete. Technique of manufacture: coil-built, wheel-turned. Surface Treatment: Polished slip. Decoration: outer applied $(2 \mathrm{knobs}+1$ vertical ridge $)+$ outer reserved burnished. Dating: EB IIIB. Bibliography: Rast - Schaub 1989, fig. 202:2.

No. 6 - Red polished jug with Reserved Alternate-Hatching Decoration (fig. 2:4)

Provenance: Area J, Tell el-Mutesellim/Megiddo. Excavation: Tel Aviv University/George Washington University expeditions; Class: Red Polished Ware. State of preservation: missing part of the neck. Technique of manufacture: coil-built, wheel-turned. Surface Treatment: Polished slip. Decoration: outer applied (1 vertical ridge) + outer reserved burnished. Dating: EB IIIB (phase J-6a). Bibliography: Adams 2013a, 324-325, fig. 8.14:3 No. 7 - Red polished jug with Reserved Alternate-Hatching Decoration (fig. 2:5)

Provenance: Area J, Tell el-Mutesellim/Megiddo. Excavation: Tel Aviv University/George Washington University expeditions; Class: Red Polished Ware. State of preservation: complete. Technique of manufacture: coil-built, wheel-turned. Surface Treatment: Polished slip. Decoration: outer applied (1 vertical ridge) + outer reserved burnished. Dating: EB IIIB (phase J-6a). Bibliography: Adams 2013a, 324-325, figs. 8.14:2, 8.15. 


\section{REFERENCES}

ADAMS, M.J.

2013a The Early Bronze Age Pottery from Area J: I. Finkelstein - D. UssishKin - E.H. Cline (eds.), Megiddo V: the 2004-2008 seasons (Tel Aviv Monograph Series 31), Vol. II, Tel Aviv 2013, pp. 295-334.

2013b Part III. The Main Sector of Area J: I. FinkELstein - D. UssishKIN - E.H. Cline (eds.), Megiddo V: the 2004-2008 seasons (Tel Aviv Monograph Series 31), Vol. I, Tel Aviv 2013, pp. 47-118

ADAMS, M.J. - FinKELSTEIN, I. - USSISHKIN, D.

2014 The Great Temple of Early Bronze I Megiddo: American Journal of Archaeology 118/2 (2014), pp. 285-305.

AMIRAN, R.

1969 Ancient Pottery of the Holy Land, From the Prehistoric to the Persian Period, Jerusalem 1969.

1974 The Painted Pottery Style of the Early Bronze II Period in Palestine: Levant 6 (1974), pp. 65-68.

Amiran, R. - PARAn, U. - Shiloh, Y. - Brown, R. - Tsafrir, Y. - Ben-Tor, A.

1978 Early Arad. The Chalcolithic Settlement and Early Bronze City, I. First - Fifth Seasons of Excavations, 1962-1966 (Judean Desert Studies), Jerusalem 1978.

CALlaway, J.A.

1980 The Early Bronze Age Citadel and Lower City at 'Ai (et-Tell): A Report of the Joint Archaeological Expedition to 'Ai (et-Tell) No. II (Colt Archaeological Institute Publications), Cambridge 1980.

Chesson, M. S. - Philip, G.

2003 Tales of the city? 'Urbanism' in the Early Bronze Age Levant from Mediterranean and Levantine perspectives: Journal of Mediterranean Archaeology 16 (2003), pp. 3-16.

CHESSON, M.S. - GoOdALE, N.

2014 Population aggregation, residential storage and socioeconomic inequality at Early Bronze Age Numayra, Jordan: Journal of Anthropological Archaeology 35 (2014), pp. 117-134.

DOUGLAS, K.

2007 Die Befestigung der Unterstadt von Hirbet ez-Zeraqon im Rahmen der frühbronzezeitlichen Fortifikationen in Palästina (Abhandlungen des Deutschen Palästina-Vereins 27.3), Wiesbaden 2007.

EsSE, D.L.

1989 Secondary State Formation and Collapse in Early Bronze Age Palestine: P. DE Miroschedji (ed.), L'Urbanisation de la Palestine a l'âge du Bronze ancien. Bilan et prospectives des recherches actuelles. Actes du Colloques d'Emmaus (20-24 octobre 1986) (British Archaeological Reports International Series 527), Oxford 1989, pp. 81-96.

Fiaccavento, C

2013 Potters' wheels from Khirbet al-Batrawy: A Reconsideration of Social Contexts: Vicino Oriente XVII (2013), pp. 75-103.

FinKELSTEIN, I. - USSISHKIN, D.

2000 Archaeological and Historical Conclusions: I. FINKELSTEIN - D. USSISHKIN - B. HALPERN (eds.), Megiddo III: The 1992-1996 Seasons (Tel Aviv Monograph Series 18). Tel Aviv 2000, pp. 576-605. 
Finkelstein, I. - Ussishrin, D.- PeERsman, J.

2006 Area J (The 1998-2000 Seasons): I. FinKELSTEIN - D. UsSiSHKIN - B. HALPERN (eds.), Megiddo IV. The 1998-2002 Seasons (Tel Aviv Monograph Series 25), Tel Aviv 2006, pp. 29-53.

GALLO, E.

2014 Destructions in Early Bronze Age Southern Levant: L. NigRo (ed.), Overcoming Catastrophes. Essays on disastrous agents characterization and resilience strategies in pre-classical Southern Levant (Rome «La Sapienza» Studies on the Archaeology of GARSTANG, J. Palestine \& Transjordan 11), Rome 2014, pp. 144-169.

1932 Jericho: City and Necropolis: Liverpool Annals of Archaeology and Anthropology 19 (1932), pp. 3-22, 35-54.

1933 Jericho: city and necropolis. 4. Tombs of MBAii. 5. Tombs of MBAii and LBAi.6. The Palace Area: Liverpool Annals of Archaeology and Anthropology 20 (1933), pp. 3-42.

1934 Jericho: City and Necropolis: Liverpool Annals of Archaeology and Anthropology 21 (1934), pp. 99-136.

Garstang, J. - DroOP, J.P. - CrowfoOt, J.

1935 Jericho: City and Necropolis (Fifth Report): Liverpool Annals of Archaeology and Anthropology 22 (1935), pp. 143-184.

GARSTANG, J. - BEN-Dor, I. - FitzGERALD, G.M.

1936 Jericho: City and Necropolis (Report for the Sixth and Concluding Season, 1936): Liverpool Annals of Archaeology and Anthropology 23 (1936), pp. 67-100.

GENZ, H

2002 Die frühbronzezeitliche Keramik von Khirbet ez-Zeraqon (Abhandlungen des Deutschen Palästina-Vereins, Band 27:2), Wiesbaden 2002.

2010 Thoughts on the function of 'public buildings' in the Early Bronze Age southern Levant: D. Bolger - L.C. Maguire (eds.), Development of Pre-State Communities in the Ancient Near East, Oxbow 2010, pp. 46-52.

GREENBERG, $\mathrm{R}$

1997 Area A. The Early Bronze Age. Strata 11-10: A. BEN-ToR - R. BonfIL (eds.), Hazor V. An Account of the Fifth Season of Excavation, 1968, Jerusalem 1997, pp. 17-23.

2006 Notes on the Early Bronze Age Pottery (The 1998-2000 Seasons): I. FinKELSTEIN - D. USSISHKIn - B. HALPERN (eds.), Megiddo IV: the 1998-2002 Seasons, (Tel Aviv Monograph Series 24), Tel Aviv 2006, pp. 149-165.

GREENBERG, R. - GOREN, Y. (guest eds.)

2009 Transcaucasian Migrants and the Khirbet Kerak Culture in the Third Millennium BCE, The Sonia and Marco Nadler Institute of Archaeology Annual Symposium, March 23, 2008: Tel Aviv 36/2 (2009).

GreEnBerg, R. - PAZ, S. - Wengrow, D. - IserLis, M.

2012 Tel Bet Yerah: Hub of the Early Bronze Age Levant: Near Eastern Archaeology 75/2 (2012), pp. 88-107.

GreENBERG, R. - PORAT, N.

1996 A Third Millennium Levantine Pottery Production Centre: Typology, Petrography, and Provenance of the Metallic Ware of Northern Israel and Adjacent Regions: Bulletin of the American School of Oriental Research 301 (1996), pp. 5-24.

Greenberg, R. - Eisenberg, E. - PAZ, S. - PAZ, Y. (eds.)

2006 Bet Yerah: The Early Bronze Age Mound I: Excavations Reports 1933-1986 (Israel Antiquities Authority Reports 30), Jerusalem 2006. 
KANTOR, $\mathrm{H}$.

1992 The Relative Chronology of Egypt and its Foreign Correlations before the First Intermediate Period: R.W. EHRICH (éd.), Chronologies in Old World Archaeology, Chicago 1992, pp. 3-21.

KENYON, K.M.

1960 Excavations at Jericho. Volume One. The Tombs excavated in 1952-1954, London 1960.

1965 Excavations at Jericho. Volume Two. The Tombs excavated in 1955-1958, London 1965.

KENYON, K.M. - Holland, T.A.

1983 Excavations at Jericho. Volume Five. The Pottery Phases of the Tell and Others Finds,

LOUD, G.

1948 Megiddo II. Seasons of 1935-1939 (Oriental Institute Publications 62), Chicago 1948.

MAZAR, A.

1990 Archaeology of the Land of the Bible, 10000 - 586 B.C.E., New York 1990.

DE MiroschedJI, P.

1990 The Early Bronze Age Fortifications at Tel Yarmut - An Interim Statement: Eretz Israel 21 (1990), pp. 48*-61*.

2000 An Early Bronze Age III Pottery Sequence for Southern Israel: G. PHILIP - D. BAIRD (eds.), Ceramics and Change in the Early Bronze Age of Southern Levant (Levantine Archaeology 2), Sheffield 2000, pp. 315-345.

2003 The Late Early Bronze Age III Palace B1 at Tel Jarmuth: a descriptive summary: Eretz Israel 27 (2003), pp. 153*-170*.

2009 Rise and collapse in the Southern Levant in the Early Bronze Age: Scienze dell'Antichità 15 (2009), pp. 101-129.

NigRo, L.

1994 Ricerche sull'architettura palaziale della Palestina nelle età del Bronzo e del Ferro (Contributi e Materiali di Archeologia Orientale V), Roma 1994.

2009 Khirbet al-Batrawy: A Case Study of $3^{\text {rd }}$ Millennium Urbanism in North-Central Jordan: D. Clark - B. PorTer (eds.), Studies in History and Archaeology of Jordan X (2009), pp. 657-677.

2010a In the Palace of the Copper Axes/Nel Palazzo delle Asce di Rame. Khirbet al-Batrawy: the discovery of a forgotten city of the III millennium BC in Jordan/Khirbet al-Batrawy: la scoperta di una città dimenticata del III millennio a.C. in Giordania (Rome «La Sapienza» Studies on the Archaeology of Palestine \& Transjordan/Colour Monographs I), Rome 2010.

$2010 \mathrm{~b}$ Between the Desert and the Jordan: Early Urbanization in the Upper Wadi az-Zarqa - the EB II-III fortified town of Khirbet al-Batrawy: P. MAtTHIAE - F. PinNOCK - L. NigRO - N. MARChETti (eds.), 6 ICAANE. Proceedings of the 6th International Congress of the Archaeology of the Ancient Near East. 5 May - 10 May 2008, "Sapienza”, Università di Roma, Wiesbaden 2010, Vol. 2, pp. 431-458.

2010c Quattro asce di rame dal Palazzo B di Khirbet al-Batrawy (Bronzo Antico IIIB, 25002300 a.C.): Scienze dell'Antichità 16 (2010), pp. 561-572.

$2010 \mathrm{~d} T$ Tell es-Sultan/Jericho in the Early Bronze II (3000-2700 BC): the rise of an early Palestinian city. A synthesis of the results of four archaeological expeditions (Rome «La Sapienza» Studies on the Archaeology of Palestine \& Transjordan 5), Rome 2010.

2011 Dominating the River: Khirbet al-Batrawy, an EB II-III City in North-Central Jordan: Syria 88 (2011), pp. 59-74.

2012 An EB IIIB (2500-2300 BC) gemstones necklace from the Palace of the Copper Axes at Khirbet al-Batrawy, Jordan: Vicino Oriente XVI (2012), pp. 227-243. 
2013 Khirbet al-Batrawy. An Early Bronze Age city at the fringes of the desert: Syria 90 (2013), pp. 189-209.

2014a The copper route and the Egyptian connection in $3^{\text {rd }}$ Millennium BC Jordan seen from the caravan city of Khirbet al-Batrawy: Vicino Oriente XVIII (2014), pp. 39-64.

2014b The King's Cup and the Bear Skin: Royal Ostentation in the Early Bronze III "Palace of the Copper Axes" at Khirbet al-Batrawy?: Z. KAFAFI - M. MARAQTEN (eds.), A Pioneer of Arabia. Studies in the Archaeology and Epigraphy of the Levant and the Arabian Peninsula in Honor of Moawiyah Ibrahim (Rome «La Sapienza» Studies on the Archaeology of Palestine \& Transjordan 10), Rome 2014, pp. 261-270.

2014c The Archaeology of Collapse and Resilience: Tell es-Sultan/ancient Jericho as a Case Study: L. Nigro (ed.), Overcoming Catastrophes. Essays on disastrous agents characterization and resilience strategies in pre-classical Southern Levant (Rome «La Sapienza» Studies on The Archaeology of Palestine And Transjordan 11), Rome 2014, pp. 55-85.

NigRO, L. (ed.)

2006 Khirbet al-Batrawy. An Early Bronze Age Fortified Town in North-Central Jordan. Preliminary Report of the First Season of Excavations (2005) (Rome «La Sapienza» Studies on the Archaeology of Palestine \& Transjordan 3), Rome 2006.

2008 Khirbet al-Batrawy II. The EB II city-gate, the EB II-III fortifications, the EB II-III temple. Preliminary report of the second (2006) and third (2007) seasons of excavations (Rome «La Sapienza» Studies on the Archaeology of Palestine \& Transjordan 6), Rome 2008.

2011 Khirbet al-Batrawy III. The EB II-III triple fortification line and the EB IIIB quarter inside the city. Preliminary report of the fourth (2008) and fifth (2009) seasons of excavations (Rome «La Sapienza» Studies on the Archaeology of Palestine \& Transjordan 8), Rome 2011.

NigRO, L. - SALA, M.

2011 Preliminary Report on the Sixth (2010) Season of Excavation by "La Sapienza" University of Rome at Khirbat al-Batrāwī (Upper Wādī az-Zarqā'): Annual of the Department of Antiquities of Jordan 55 (2011), pp. 85-100.

2012 Preliminary Report of the Sixth Season (2011) of Excavations by the University of Rome "La Sapienza" at Khirbat al-Batrāwī (Upper Wādī az-Zarqā'): Annual of the Department of Antiquities of Jordan 56 (2012), pp. 45-53.

NigRo, L. - SAla, M. - TAHA, H. - YASSine, J.

2011 The Early Bronze Age Palace and Fortifications at Tell es-Sultan/Jericho. The 6th - 7th seasons (2010-2011) by Rome "La Sapienza" University and the Palestinian MOTADACH: Scienze dell’Antichità 17 (2011), pp. 571-597.

Pelta, R.

2013 Experimental Archaeology: Investigating a Unique Burnishing Technique on an Early Bronze III Jug: I. FinkelsteIN - D. UssishKIN - E.H. Cline (eds.), Megiddo V: the 20042008 seasons ( Tel Aviv Monograph series 31), Tel Aviv 2013, Vol. II, pp. 335-342.

PHILIP, G.

2008 The Early Bronze I-III Ages: R. AdAms (ed.), Jordan. An Archaeological Reader, London - Oakville 2008, pp. 161-226.

RAST, W.E. - SCHAUB, R.T.

1989 Bâb edh-Dhrâ': Excavations in the Cemetery directed by Paul W. Lapp (1965-67) (Reports of the Expedition to the Dead Sea Plain, Jordan, Volume I), Winona Lake 1989. 
Regev, J. - De Miroschedj, P. - Greenberg, R. - Brun, E. - Greenhut, Z. - Bohretto, E.

2012 Chronology of the Early Bronze Age in the Southern Levant: New Analysis for a High Chronology: Radiocarbon 54 (2012), pp. 525-566.

RouX, V. - DE MIROSCHEDJI, P.

2009 Revisiting the History of the Potter's Wheel in the Southern Levant: Levant 41/2 (2009), pp. 155-173.

SAGHIEH, M.

1983 Byblos in the Third Millennium B.C., Warminster 1983.

SALA, M.

2008 L'architettura sacra della Palestina nell'età del Bronzo Antico I-III (Contributi e Materiali di Archeologia Orientale XIII), Roma 2008.

2012 An EB IVB (2200-2000 BC) Farmers' Community at Khirbet al-Batrawy (North-Central Jordan): R. MATTHEwS - J. CURTIS (eds.), Proceedings of the 7th International Congress on the Archaeology of the Ancient Near East. 12 April - 16 April 2010, the British Museum and UCL, London, Wiesbaden 2012, pp. 697-706.

2013 A Stratified Third Millennium BC Pottery Sequence from North-Central Jordan: The EB II-III Repertoire of Khirbat al-Batrāwī: F. AL-HMOud (ed.), Studies in the History and Archaeology of Jordan XI (2013), Amman 2013, pp. 585-612.

2014 EB II-III aegyptiaca east of the Jordan: a reevaluation of trade and cultural interactions between Egypt and Transjordanian urban centres: Vicino Oriente XVIII (2014), pp. 65-82. TuBB, J.N.

1993 Sa 'idiyeh, Tell es-: E. STERN (ed.), The New Encyclopedia of Archaeological Excavations in the Holy Land, vol. 4, Jerusalem 1992, pp. 1295-1300.

TuBB, J.N. - DORRELL, P.G. - COBBING, F.J.

1997 Interim report of the ninth season (1996) of excavations at Tell el-Sa'idiyeh, Jordan: Palestine Exploration Quarterly 129 (1997), pp. 54-77.

TUFNELL, O. - WARD, W.A.

1966 Relations between Byblos, Egypt and Mesopotamia at the End of the Third Millennium B.C.: Syria 43 (1966), pp. 161-241. 

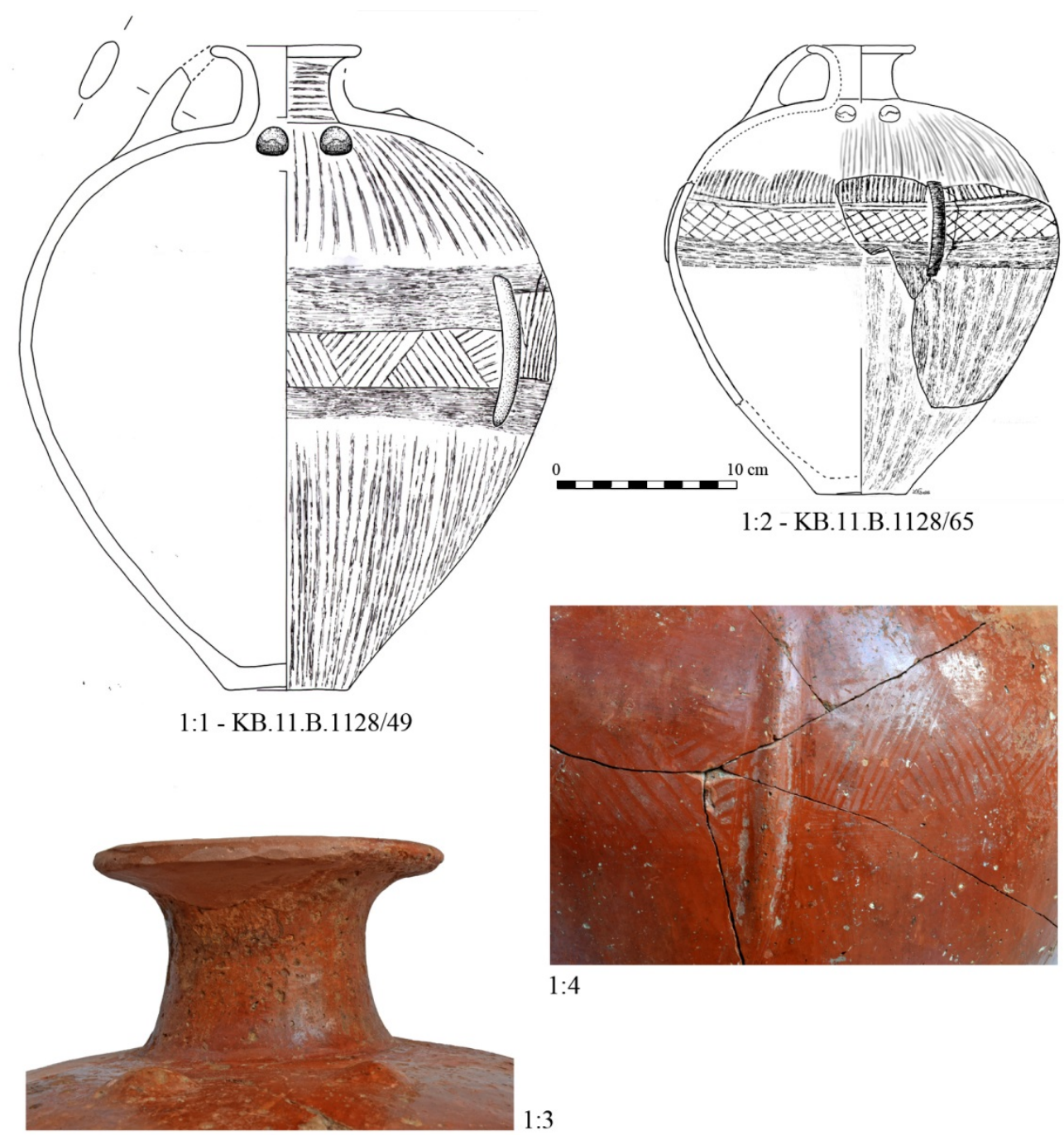

$1: 4$

$1: 3$

Fig. 1- Red burnished jugs from Khirbet al-Batrawy. 1:1 - drawing of jug KB.11.B.1128/49 with reserved alternate hatched decoration (RAHD), ridges on the girth and knobs on the shoulder, from destruction layer F.1128 in Hall L.1110; 1:2 - reconstructive drawing of jug KB.11.B.1128/65, with cross-hatched decoration and vertical ridge; 1:3 - detail of jug KB.11.B.1128/49 with the two knobs at the bottom of the neck; $1: 4$ - detail of jug KB.11.B.1128/49 with the vertical ridge on the girth and the RAHD (photo courtesy: ROSEPAJ 2014). 


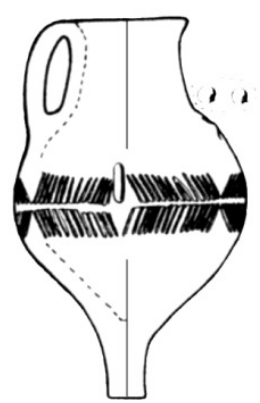

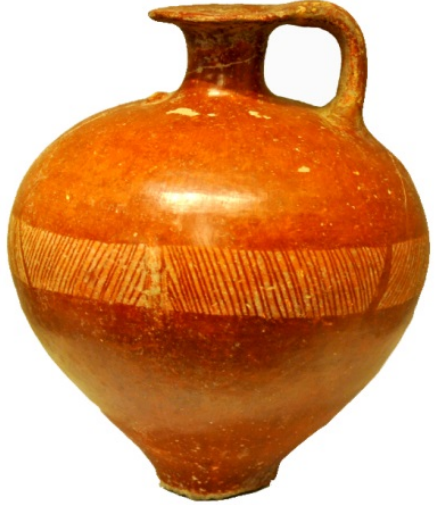

2

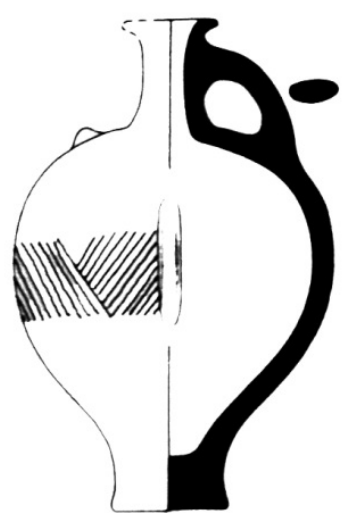

3

$0--=-10$

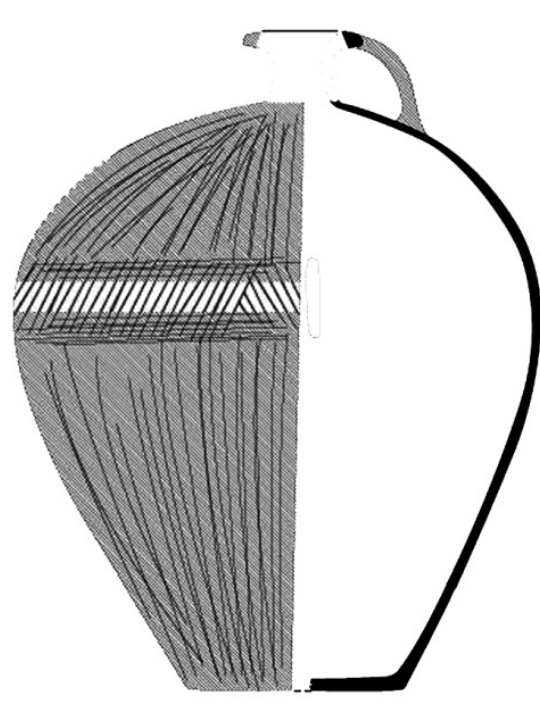

4

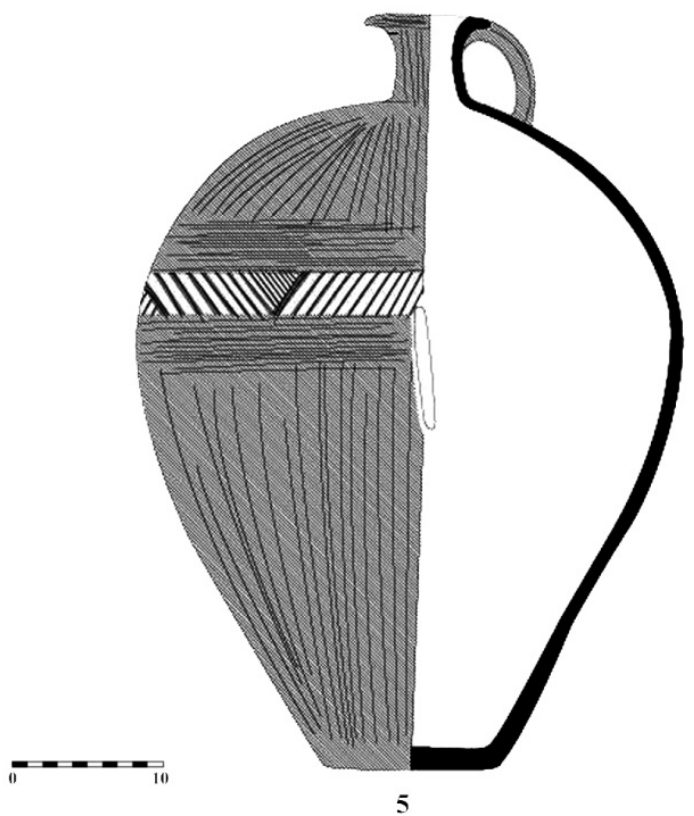

Fig. 2 - All the specimens where the Reserved Alternate-Hatching Decoration is attested. 2:1 - Tell es-Sultan/Jericho; 2:2 - Beit Ula (Hebron) (Photo (C) The Israel Museum, Jerusalem); 2:3 - Bab edh-Dhra'; 2:4-5 - Tell el-Mutesellim/Megiddo. 

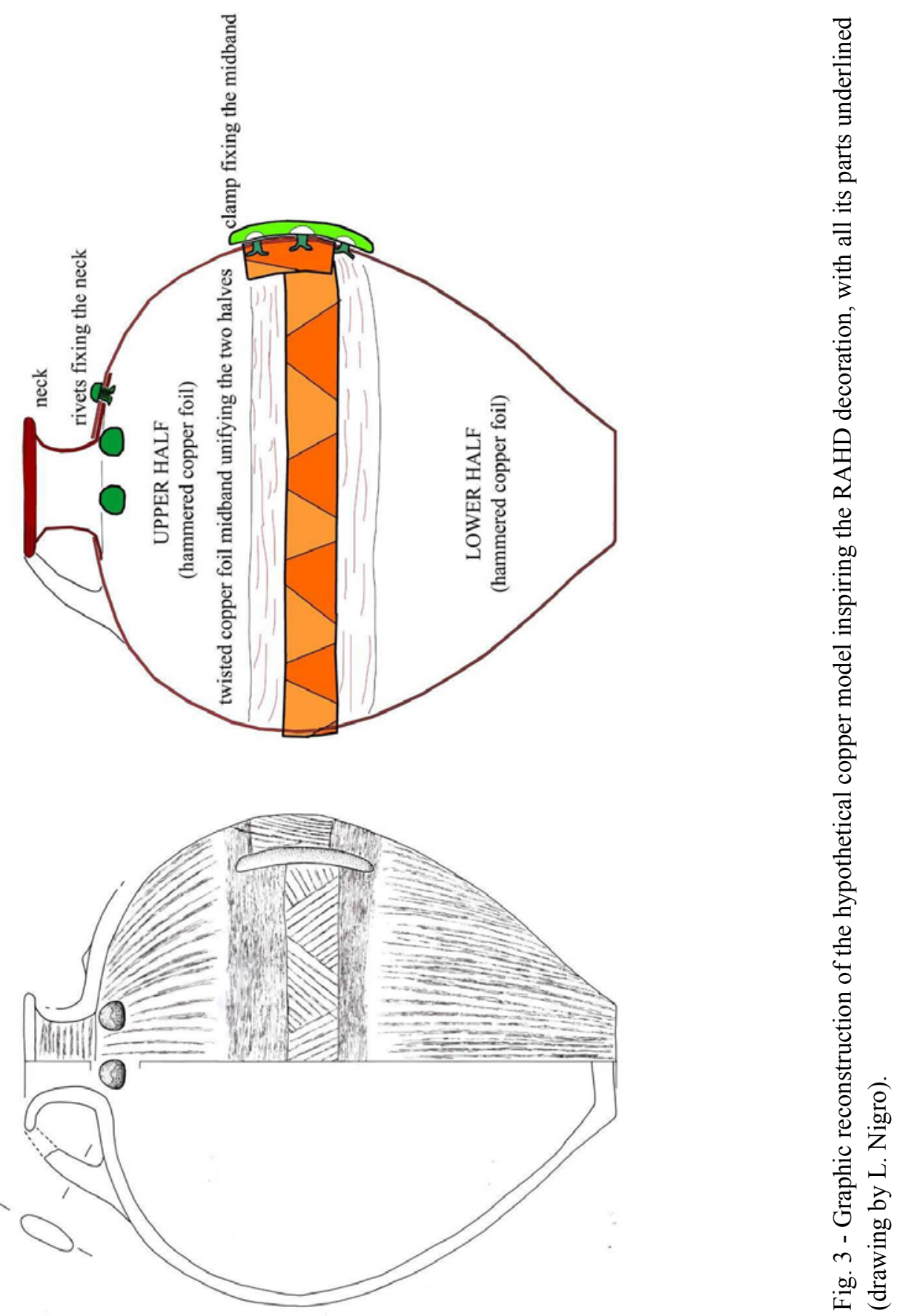